\title{
Third-Party Consent Searches: An Alternative Analysis
}

In recent years, the Supreme Court has abandoned exclusive reliance on property concepts in deciding whether certain police searches violate the fourth amendment; instead it has increasingly recognized the privacy rights of individuals. ${ }^{1}$

As a concept of general applicability, privacy has been defined as the "ability of the actor to maintain the integrity of his privacy unit." One commentator has described control over the privacy unit as "the legally recognized freedom or power of an individual (group, association, class) to determine the extent to which another individual (group, association, class, or government) may ... obtain or reveal information about him or those for whom he is personally responsible, or ... intrude physically or in more subtle ways into his life space and his chosen activities."3

Although privacy concepts have been used in the fourth amendment area to define when the government can unilaterally intrude upon an individual's interests, ${ }^{4}$ they have not been applied to the question of when one individual can validate a governmental intrusion upon another individual's interests. That question is presented in its most difficult form when two people share a possessory interest in property, and one consents to a police search directed against the other. Most courts have held that the first person can consent if he has a possessory interest in the property equal or superior to that of the person whose actions are the focus of the search. ${ }^{5} \mathrm{~A}$ pure property test, however, fails to reflect the Supreme Court's recognition that an individual's fourth amendment protections should not be dependent solely upon his property interests.

1 See, e.g., Alderman v. United States, 394 U.S. 165 (1969); Mancusi v. DeForte, 392 U.S. 364 (1968); Katz v. United States, 389 U.S. 347 (1967). See generally Kitch, Katz v. United States: The Limits of the Fourth Amendment, 1968 SuP. Cr. REv. 133; Note, From Private Places to Personal Privacy: A Post-Katz Study of Fourth Amendment Protection, 43 N.Y.U.L. REv. 968 (1968).

2 Douse, The Concept of Privacy and the Fourth Amendment, 6 U. MICH. J.L. REFORM 154, 166 (1972). See generally Fried, Privacy, 77 Yal. L.J. 475 (1968).

3 Beaney, The Right to Privacy and the American Law, 31 LAw \& Contemp. Pros. 253, 254 (1966).

4 See, e.g., cases cited note 1 supra.

6 See text and note at note 53 infra. The person whose actions are the focus of the search will hereinafter be referred to as either the suspect or the defendant. 
In Schneckloth v. Bustamonte, ${ }^{6}$ the Supreme Court recently reiterated the well-established rule that when a person whose actions are the focus of a search gives a valid consent to a police search of his premises, he cannot later claim that the search violated his fourth amendment rights. ${ }^{7}$ Although consent must be uncoerced to be valid, the Court held that consent could be considered voluntary without a showing that the consenting party knew he had the right to refuse the police request. It rejected the position that a warning similar to that required by the Court in Miranda v. Arizona $a^{8}$ is necessary to legitimize the consent. ${ }^{9}$

Whatever the merits of this decision with respect to the consent of the person against whom the search is directed, it presents acute diffculties when consent is obtained from a third party ${ }^{10}$ who shares possessory and privacy interests with the suspect. ${ }^{11}$ Where consent is obtained from the suspect, the consequences of a search are likely to have been considered. The suspect normally will have knowledge of the reason for the police request, regardless of his awareness of his right to refuse. He has a direct interest in the outcome of the search and might find cooperation with the authorities a beneficial strategy for a subsequent defense. The state of mind of the consenting third party, however, is generally quite different from that of the consenting suspect. The third party, who is usually the suspect's spouse or cotenant, is often ignorant of his coinhabitant's activities. His response to the

6412 U.S. 218 (1973).

7 Schneckloth v. Bustamonte, 412 U.S. 218 (1973); Zap v. United States, 328 U.S. 624 (1946); Davis v. United States, 328 U.S. 582 (1946).

8384 U.S. 436 (1966). In Miranda, the Court held that where a defendant is in custody, or his freedom significantly restricted, his privilege against self-incrimination must be protected by procedural safeguards. He must be informed that he has a right to remain silent, that anything he says may be used against him in court, that he has a right to consult a lawyer, and that if he cannot afford one, a lawyer will be appointed.

9 The Court's holding that a procedural warning is not required was grounded on the belief that a determination of voluntariness based on the facts of each case is sufficient to ensure that the suspect's fourth amendment rights are protected. The Court also indicated its belief that a warning requirement would be so difficult for the courts and the police to administer as to be unjustifiable.

10 "Third party" will hereinafter be used to refer to a person who shares with the suspect possession and control over the property to be searched, but who is not himself a suspect.

11 Where the suspect has no possessory or privacy interests in the premises to be searched, he has no fourth amendment rights that are violated by a consent by one in possession and control of the premises. The situation where consent is sought to search premises in which the suspect has no interest does raise some problems of unknowing or impelled consents that result in infringement of the consenter's fourth amendment protections or those of anyone who shares his privacy unit. As a matter of controlling police behavior, it might be argued that protections should be provided in such situations. This comment, however, does not consider the situation where the suspect has no interest in the premises to be searched. 
official request is not likely to be based on the kind of calculation the suspect would make about permitting an immediate police search. Instead the consent may be the result of the intimidating effect of the official request, confusion over whether refusal will be interpreted as an admission of the coinhabitant's guilt or the consenter's involvement, desire to remove what the consenter may feel certain is unwarranted suspicion, or simple indifference.

In Schneckloth the Court stated that an accommodation must be reached between effective law enforcement and the deeply held belief that criminal laws must not be used as an "instrument of unfairness."12 Although the accommodation reached in Schneckloth may be appropriate as to suspect consenters, the increased risk of impelled, unknowing, or indifferent consent present in third-party consents indicates that a different accommodation is required. Greater protections than those provided by Schneckloth are necessary where a third party, by consenting to a search, in effect diminishes another's constitutional protections. The problem of the ignorant or inadvertent third-party consent that allows invasion of another's privacy could be mitigated by a requirement of procedural warnings. The Court's finding that such warnings are administratively unfeasible in the suspect consent situation, ${ }^{13}$ however, reflects poorly on the desirability of warnings in thirdparty consent cases.

This comment examines the general development of fourth amendment theory into a propertied privacy doctrine, and reviews the current property-oriented third-party consent doctrines. The comment then suggests, as a solution to the problems of third-party consents, a framework for analyzing third-party consents that reflects recent recognition of personal rights of privacy. Under the proposed model a "consent search"14 is constitutional only where the consenting party has rights of possession and control of the premises at least equal to those of the defendant, and an interest in consenting sufficient to countervail, and thus render unreasonable, the defendant's expectation that the third party will not consent to an invasion of the defendant's privacy. A review of recent third-party consent cases reveals that the concept of "countervailing interest" essential to this model may be defined in a way that permits easy application of the test by the police and the courts. It is suggested that the model provides an administratively feasible means of minimizing unknowing and impelled third-party

12412 U.S. at 225.

13 Id. at 231.

14 The term "consent search" will be used in this comment to refer to searches that would violate the defendant's fourth amendment protections but for the consent of a person other than the defendant. 
consents without eliminating many of the benefits to law enforcement that third-party consents provide.

\section{Search and Seizure Doctrine: From Property to - Propertied Prtvacy}

The protections of the fourth amendment ${ }^{15}$ are directed against violations of personal security by the sovereign; ${ }^{16}$ searches conducted by private individuals, whether lawful or unlawful, are not proscribed by the amendment. ${ }^{1 \tau}$ The amendment does not forbid all searches conducted by government officials, only unreasonable ones. Traditional analysis uses as a threshold question whether the search requires entry into a "protected area."18 A search of a protected area normally requires the issuance of a search warrant in order to become reasonable. ${ }^{19}$ In certain situations-such as a search incident to a valid arrest ${ }^{20}$ or consent by the suspect ${ }^{21}$ or a third party ${ }^{22}$ - a warrantless search of a protected area may be reasonable. ${ }^{23}$

15 "The right of the people to be secure in their persons, houses, papers, and effects, against unreasonable searches and seizures, shall not be violated, and no Warrants shall issue, but upon probable cause, supported by Oath or affirmation, and particularly describing the place to be searched, and the persons or things to be seized." U.S. CONST. amend. IV.

16 The sanction of the exclusionary rule, whereby evidence obtained in an unreasonable search is not admissible in court, established for federal courts in Weeks v. United States, 232 U.S. 383 (1914), was applied to the states in Mapp v. Ohio, 367 U.S. 643 (1961).

17 Burdeau v. McDowell, 256 U.S. 465 (1921). But where the third party is acting at the suggestion or direction of the police, the proscription of the amendment does apply. See, e.g., Corngold v. United States, 367 F.2d I (9th Cir. 1966); Machlan v. State, 248 Ind. 218, 225 N.E.2d 762 (1967); State v. Scrotsky, 39 N.J. 410, 189 A.2d 23 (1963). See also Comment, Private Party Searches and Seizures-A Province of the Fifth Amendment, 3 U. SAN FRan. L. Rev. 159 (1968); Comment, The Applicability of the "New" Fourth Amendment to Investigations by Secret Agents: A Proposed Delineation of the Emerging Fourth Amendment Right to Privacy, 45 WAsH. L. REv. 785 (1970).

18 The term "protected area" appears only in recent cases. See, e.g., Lanza v. New York, 370 U.S. 139 (1962). Nevertheless, it provides a convenient short form of expressing concepts implicit in earlier fourth amendment case law. For a general discussion of property concepts in fourth amendment analysis, see Dutile, Some Observations on the Supreme Court's Use of Property Concepts in Resolving Fourth Amendment Problems, 21 CatHolic U.L. REv. 1 (1971).

19 Failure to obtain a warrant when one is necessary renders all evidence produced from the search inadmissible at trial. Mapp v. Ohio, 367 U.S. 643 (1961); Weeks v. United States, 232 U.S. 383 (1914). Violation of the fourth amendment's protections against unreasonable searches and seizures by government agents may also give rise to a cause of action for damages against the agents. Bivens v. Six Unknown Named Agents of Fed. Bureau of Narcotics, 403 U.S. 388 (1971).

20 See, e.g., Chimel v. California, 395 U.S. 752 (1969); Draper v. United States, 358 U.S. 307 (1959); United States v. Rabinowitz, 339 U.S. 56 (1950); Harris v. United States, 331 U.S. 145 (1947). Where the arrest is merely a pretext to conduct a search, the search may be unconstitutional. See Jones v. United States, 357 U.S. 493 (1958).

21 See cases cited note 7 supra.

22 See, e.g., United States v. Ellis, 461 F.2d 962 (2d Cir.), cert. denied, 409 U.S. 866 
The courts traditionally relied heavily upon property concepts to determine the scope of protected areas. Thus a business office, ${ }^{24}$ a hotel, $^{25}$ a rooming house, ${ }^{26}$ and a taxicab ${ }^{27}$ were constitutionally pro. tected areas, but a jail visiting room ${ }^{28}$ and an open field ${ }^{29}$ were not.

Even the early fourth amendment cases, however, contain indications that the Supreme Court recognized that possessory property rights were not the sole appropriate way of defining that area from which a person had a right to exclude government agents.

In Ex parte Jackson, ${ }^{30}$ for example, Justice Field held that a warrant is required before postal inspectors can "invade the secrecy of letters and such sealed packages in the mail." 31 And in Boyd v. United States, the Court dealt with a subpoena of personal papers as both a violation of the fifth amendment and a violation of the fourth amendment, with little distinction made between the two types of protection.

Gradually it has become clearer that the fourth amendment right to prevent governmental intrusions is a personal right of individuals rather than a right attaching to property and exercisable only by those with certain rights in that property. In Olmstead $v$. United States, ${ }^{33}$

(1972); United States v. Eldridge, 302 F.2d 463 (4th Cir. 1962); Commonwealth v. Biebighauser, 450 Pa. 336, 300 A.2d 70 (1973).

23 The Supreme Court has held that exceptions to the warrant requirement are to be narrowly construed. See, e.g., Chimel v. California, 395 U.S. 752 (1969); Trupiano v. United States, 334 U.S. 699 (1948). In addition to the search incident to a valid arrest and consent exceptions, the Court has held that where police are in "hot pursuit" of a suspect, they need not delay their investigation to obtain a search warrant if to do so would gravely endanger their own or others' lives. Warden v. Hayden, 387 U.S. 294 (1967). A warrantless search of an automobile or other vehicle may be conducted where it is not practical to obtain a search warrant because the vehicle may be moved quickly. See, e.g., Chambers v. Maroney, 399 U.S. 42 (1970); Carroll v. United States, 267 U.S. 132 (1925). Two other exceptions to the search warrant requirement do not share the emergency nature of the above situations. First, police may seize an object without a search warrant if it is seen, "in plain view," from a place where the police have a lawful right to be. Harris v. United States, 390 U.S. 234 (1967). Second, where property has been abandoned police may search the property without a warrant. Abel v. United States, 362 U.S. 217 (1960). A determination of abandonment rests on consideration of the factual circumstances of the defendant's alleged act of abandonment and his intent in carrying out such actions.

24 Silverthorne Lumber Co. v. United States, 251 U.S. 385 (1920).

25 Lustig v. United States, 338 U.S. 74 (1949).

26 McDonald v. United States, 335 U.S. 451 (1948).

27 Rios v. United States, 364 U.S. 253 (1960).

28 Lanza v. New York, 370 U.S. 139 (1962).

29 Hester v. United States, 265 U.S. 57 (1924).

3096 U.S. 727 (1878).

31 Id. at 733.

32116 U.S. 616 (1886).

33277 U.S. 438 (1928). 
Justice Brandeis argued, in dissent, for less reference to property interests in determining the reasonableness of a government search. ${ }^{34}$ In Jones $v$. United States, ${ }^{35}$ the Court moved in the direction suggested by Justice Brandeis and rejected the procedural rule requiring that standing to object to a search be premised on ownership or possession of the property searched. ${ }^{36}$ The subtle distinctions of property law were deemed inappropriate for determining what interests are protected against governmental intrusions. ${ }^{37}$ Likewise, in Warden $v$. Hayden, ${ }^{38}$ the Court stated: "We have recognized that the principal object of the Fourth Amendment is the protection of privacy rather than property, and have increasingly discarded fictional and procedural barriers rested on property concepts." 39

In Katz $v$. United States, ${ }^{40}$ the Court ruled inadmissible evidence that FBI agents had obtained by attaching an electronic listening and recording device to the outside of a public telephone booth. The crucial question, the Court said, was not whether the governmental action constituted a physical invasion of a physically defined "protected area," but rather whether the governmental action constituted an intrusion against which the individual had properly sought protection. Thus, "[w] hat a person knowingly exposes to the public, even in his own home or office, is not a subject of Fourth Amendment protection," whereas "what he seeks to preserve as private, even in an area accessible to the public, may be constitutionally protected." 41 The Court seemed to suggest that the protections of the fourth amendment were no longer to be dependent upon the locus of the search or the property rights a

34 "The makers of our Constitution . . . conferred, as against the Government, the right to be let alone-the most comprehensive of rights and the right most valued by civilized men. To protect that right, every unjustifiable intrusion by the Government upon the privacy of the individual, whatever the means employed, must be deemed a violation of the Fourth Amendment." 277 U.S. at 478. See also Brandeis \& Warren, The Right to Privacy, 4 HARv. L. REv. 193 (1890).

35362 U.S. 257 (1960).

36 The particular difficulty attacked was the situation where a defendant charged with a possessory crime had to admit possession in order to gain standing to challenge the search.

37 The test formulated in Jones was that anyone "legitimately on the premises," could challenge the legality of the search, 362 U.S. at 267, which itself creates difficulties of definition. See LaFave, Search and Seizure: "The Course of True Law . . . Has Not . . . Run Smooth," 1966 ILL. L.F. 255; Symposium-Gonstitutional Problems in the Administration of Criminal Law, 59 Nw. U.L. REv. 610 (1964). Nevertheless, the shift away from tying fourth amendment protections to ownership-type property rights was clear.

38387 U.S. 294 (1967).

39 Id. at 304 . The Court rejected the distinction between evidentiary articles, which could not be seized, and instrumentalities of the crime, which could.

40389 U.S. 347 (1967).

41 Id. at 351-52. 
person has in the area physically invaded. The majority opinion in Katz failed to give any criteria by which lower courts could define the scope of the protections. In a concurring opinion, however, Justice Harlan suggested that a two-step requirement for fourth amendment protection had emerged-that the defendant have actually exhibited an expectation of privacy, and that such expectation be reasonable. ${ }^{42}$

Katz might have been read as the final blow to a property-based fourth amendment analysis. Property concepts, however, have not been completely discarded in determining the reasonableness of a warrantless search, first because the courts are properly reluctant to disturb long-standing definitions of the basic protections, and second because the nature of the property searched for and the area in which the search is conducted are relevant to the existence and reasonableness of the expectation of privacy. ${ }^{43}$ This post-Katz approach has been labeled by several commentators as "propertied privacy." 44

Although Harlan spoke in Katz of an actual as well as a reasonable expectation of privacy, ${ }^{45}$ the "reasonable expectation" standard has not in fact been made dependent upon the subjective expectations of the defendant. ${ }^{48}$ In practice, the effect of the privacy approach has been to extend the protections of the fourth amendment without affecting the previous property-linked protections. ${ }^{47}$ It might be possible to

42389 U.S. at 360 . For a discussion of the way in which "reasonable" should be defined, see text and note at note 46 infra.

43 See Mancusi v. DeForte, 392 U.S. 364 (1968); People v. Dumas, - Cal. 3d -, 512 P.2d 1208, 109 Cal. Rptr. 304 (1973); People v. Triggs, 8 Cal. 3d 884, 506 P.2d 232, 106 Cal. Rptr. 408 (1979); State v. Matias, 51 Haw. 62, 451 P.2d 257 (1969); People v. Nunn, 7 IIl. App. 3d 601, 288 N.E.2d 88 (1972).

44 See Kitch, supra note 1; Note, From Private Places to Personal Privacy: A Post-Katz Study of Fourth Amendment Protection, supra note 1.

45389 U.S. at 360 .

46 The opinion in Katz supports this observation. In Katz the defendant quite obviously expected surveillance, yet he was held to have an expectation of privacy. Similarly, a defendant might, with subjective reasonableness, expect that the other party to a conversation will not relate the conversation to the police. Nevertheless, the Court has held that there can be no reasonable expectation that the other party to a conversation will not reveal it when asked. See United States v. White, 401 U.S. 745 (1971); Hoffa v. United States, 385 U.S. 293 (1966); On Lee v. United States, 343 U.S. 747 (1952). In regard to this latter example, it should be noted that the framework proposed in this comment would not preclude persons from describing, in response to police questioning, things that they have seen or heard. The framework proposed here is restricted to physical searches. Thus although a brother, for example, could not consent to a police-initiated search for narcotics, he could answer police inquiries about what he has seen or heard and testify in a warrant hearing or a trial.

47 The one possible exception is Warden v. Hayden, 387 U.S. 294 (1967), where the Court overturned the property-based distinction between evidentiary objects, which could not be seized, and instrumentalities of the crime, traditionally held subject to seizure on the ground that the state had a superior property interest. The Court stated 
unify the approaches by creating a presumption that every person has a reasonable expectation of privacy within traditionally protected areas. For the purposes of this comment, however, it is sufficient to view the privacy approach as an indication of the Court's belief that in certain circumstances a person should be accorded greater control over his privacy unit than was previously accorded under property-linked fourth amendment analysis.

\section{Traditionat Justifications For Third-Party Consents}

The procedural safeguards surrounding the consent exception to the search warrant requirement have received a great deal of attention. ${ }^{48}$ A consent to a police request to search, whether given by the suspect or a third party, must be clear, knowing, and uncoerced.99 Mere acquiescence in a police officer's asserted authority is not a valid consent. ${ }^{50}$ The Court has recently determined, however, that there need be no specific warning of the right to refuse a request to search. ${ }^{51}$ Allowing a third party's consent to validate an otherwise unreasonable search has traditionally been justified by reference to property and agency concepts. These concepts, however, have not been consistently applied, and the case law on the subject is in considerable disarray. ${ }^{52}$

The ability of a third party to consent to a search has generally been justified on one of two bases: the third party's possessory or control interests in the searched area, ${ }^{63}$ or an agency relationship between the

that under the privacy approach the property-based distinction had become meaningless and held that both types of material could be seized.

48 See, e.g., LaFave, supra note 37; LaFave, Warrantless Searches and the Stpreme Court: Further Ventures into the "Quagmire," 8 CRIM. X. BuLL. 9 (1972); Note, Consent Searches: A Reappraisal After Miranda v. Arizona, 67 CoLum. L. Rev. 130 (1967).

49 The concept of "clear, knowing and uncoerced" is, however, open to much abuse. In State v. Rye, 2 Wash. App. 920, 471 P.2d 96 (1970), for example, the police were originally told by the wife of the defendant that she would not consent. Only after they told her that they would go get a search warrant did she say, "If you think there is anything in this house that is stolen ... you go ahead and find it. I am not going to help you." 471 P.2d at 98. The court held this to be a clear, knowing, and uncoerced consent.

50 In Bumper v. North Carolina, 391 U.S. 543 (1968), police falsely announced that they had a search warrant. The grandmother's consent was held invalid because it was mere acquiescence in a claim of lawful authority. In Amos v. United States, 255 U.S. 313 (1921), the Court held that where officers announced to the wife that they had come to search the premises for violations of the revenue law, there was implied coercion.

61 Schneckloth v. Bustamonte, 412 U.S. 218 (1973).

52 See, e.g., cases cited at notes 53-55 and 62 infra. See also cases gathered in LaFave, supra note 37 , at $312-22$.

53 Several jurisdictions have used this basis to hold, for example, that spouses may consent to a search. United States v. Thompson, 421 F.2d 373 (5th Cir. 1970); People v. Haskell, 41 Ill. 2d 25, 241 N.E.2d 430 (1969); Commonwealth v. Biebighauser, 450 Pa. 
consenting third party and the defendant. ${ }^{54}$ Often both justifications are invoked in a single case. ${ }^{.55}$

In Chapman v. United States, ${ }^{56}$ the Supreme Court dealt with both of these justifications while invalidating a search of a lessee's apartment conducted pursuant to the landlord's consent. The Court held that the landlord's limited possessory rights did not validate the third-party consent, and that although the landlord was expressly authorized in the lease to enter the apartment to view waste, his authority did not extend to allowing police to enter to search for incriminating evidence. ${ }^{57}$

Similar reasons underlay the Court's decision in Stoner $v$. California ${ }^{58}$ where a search of the defendant's hotel room, consented to by the night hotel clerk, was held invalid. The Court flatly rejected the prosecution's claim that the police had reasonable basis to believe that the clerk had authority to consent. In a much quoted paragraph the Court said:

336, 300 A.2d 70 (1973); Burge v. State, 443 S.W.2d 720 (Tex. Crim. App.), cert. denied, 396 U.S. 934 (1969). Some jurisdictions have held to the contrary that a spouse cannot consent to a search of the other spouse's property. E.g., State v. Pina, 94 Ariz. 243, 388 P.2d 167 (1963); Simmons v. State, 94 Okla. Crim. 18, 229 P.2d 615 (1951). Parents have been held to be able to consent. E.g., United States v. De Prima, 472 F.2d 550 (1st Cir. 1973); Maxwell v. Stephens, 229 F. Supp. 205 (E.D. Ark. 1964); McCray v. State, 236 Md. 9, 202 A.2d 320 (1964). Siblings can also consent, e.g., Shorey v. Warden, $401 \mathrm{~F} .2 \mathrm{~d} 474$ (4th Cir.), cert. denied, 393 U.S. 915 (1968); People v. Walker, 34 Ill. 2d 23, 213 N.E.2d 552 (1966), as can roommates, e.g., People v. Banks, 298 Cal. 2d 43, 47 Cal. Rptr. 499 (Dist. Ct. App. 1965).

In several jurisdictions the scope of search under the possession and control rule is limited to areas held in common. Objects in the exclusive control of the searched party, such as personal effects or locked boxes, may not be searched even with the consent of a third party with equal or superior possessory or property rights in the premises. See Holzhey v. United States, 223 F.2d 823 (5th Cir. 1955); State v. Evans, 45 Haw. 622, 372 P.2d 365 (1962).

6t See, e.g., United States v. Eldridge, 302 F.2d 463 (4th Cir. 1962); United States v. Sergio, 21 F. Supp. 553 (S.D.N.Y. 1937); Ennox v. State, 130 Tex. Crim. 328, 94 S.W.2d 473 (1936).

55 See, e.g., People v. Carter, 48 Cal. 2d 737, 312 P.2d 665 (1957); People v. Misquez, 152 Cal. App. 2d 471, 313 P.2d 206 (Ct. App. 1957).

56365 U.S. 610 (1961).

57 The possessory concepts used in Chapman are somewhat perplexing in that the property law discussion refers to Georgia law. The Court, however, did not clearly hold that state law controls the ability of a landlord to consent to a search of the leased premises. Similarly, in Stoner v. California, 376 U.S. 483 (1963) (discussed in text and note at note 59 infra), the Court noted that even if it were assumed that California law could authorize the clerk to consent, there was no indication that California law so provided. The Court's avoidance of the question of which law controls might be taken as an indication that protection against governmental intrusion is a right appertaining to the person and governed by the Constitution, rather than to the property under state law.

58376 U.S. 483 (1963). 
[T] he rights protected by the Fourth Amendment are not to be eroded by strained applications of the law of agency or by unrealistic doctrines of "apparent authority." . . . It was a right, therefore, which only the petitioner could waive by word or deed, either directly or through an agent. ${ }^{50}$

In keeping with the Supreme Court decisions in Stoner and Chapman, lower courts have generally held that persons with rights of possession inferior to those of the defendant cannot consent to a police search of the defendant's premises or effects. Employees ${ }^{60}$ and employers, ${ }^{\theta 1}$ for example, have seldom been allowed to consent to the search of the other's property. The courts have not been consistent, however, in their determination of whether bailees possess the control necessary for a valid third-party consent to a police search. ${ }^{62}$

Although a private individual with possessory rights inferior to those of the defendant does not violate the Constitution by giving incriminating evidence to the police as the fruits of a private search, ${ }^{63}$ he cannot legitimately consent to a police request to search. He is also prohibited from conducting the search at the initiation of the police; in that case his actions are considered to be governmental actions and the search must meet the warrant requirements. ${ }^{64}$

The traditional property-oriented justifications for third-party consents have not escaped criticism. ${ }^{65}$ The doctrine of implied agency has

59 Id. at 488-89. Stoner has been read by some commentators as indicating that only third-party consents given by those with express authority to permit such searches are permissible. See Note, Third Party Consent to Search and Seizure: Need for a New Evaluation, 41 ST. JoHn's L. REv. 82 (1966); Comment, Third Party Consent to Search and Seizure, 33 U. CHI. L. Rev. 797 (1966). See also United States v. Greer, 297 F. Supp. 1265 (N.D. Miss. 1960) where the court held that a wife cannot waive her husband's constitutional rights under the fourth amendment unless he has expressly authorized her to do so.

60 E.g., People v. Smith, 43 Mich. App. 400, 204 N.W.2d 308 (1972).

61 E.g., United States v. Blok, 188 F.2d 1019 (D.C. Cir. 1951) (official superior in government office consented to search of employee's desk).

62 In United States v. Eldridge, 302 F.2d 463 (4th Cir. 1962), the court held that where the defendant loaned his car to a party who later consented to a police search, the delegation of authority was sufficient to imply an agency relationship. But see State v. Bernius, 177 Ohio St. 155, 203 N.E.2d 241 (1964).

63 See cases cited note 80 infra; United States v. Blok, 188 F.2d 1019 (D.C. Cir. 1951); United States v. Small, 297 F. Supp. 582 (D. Mass. 1969). The court in Blok held that it was permissible for the employer to give the police evidence that he discovered while looking for office papers or supplies in employee's desk, but he could not consent to a police search of the desk. In Small, the court stated that although the locker inspector had the right to view the locker's contents, he could not consent to a search of the defendant's locker by law enforcement officials.

64 In searches conducted by a private individual, government involvement at any stage of the search is sufficient to bring the exclusionary rule into play. Lustig v. United States, 338 U.S. 74 (1949); cf. United States v. Ogden, 484 F.2d 1274 (9th Cir. 1973).

65 See Comment, The Effect of a Wife's Consent to a Search and Seizure of the Hus- 
seemed particularly vulnerable to criticism as a fiction designed to allow police to conduct what would otherwise be an unreasonable search and seizure. In consent searches agency must almost always be inferred, and this inference must be made from facts that in other circumstances would not support a finding of implied agency. ${ }^{66}$

The conceptual framework underlying the possession and control justification is less vulnerable to the charge of convenient fictionalism. Possession and control of the premises normally does carry with it the recognized right to admit social visitors, salesmen, and even police. The issue, however, is whether one person's equal or even superior possessory rights should be allowed to override another's possessory plus privacy interest. Although each occupant has both possessory and privacy interests in the premises, police generally inform occupants of their identity and their purpose, ${ }^{67}$ thus revealing whose privacy interest they seek to invade.

A corollary of the possession and control justification is the "assumption of risk" doctrine. Under this concept it is argued that by trusting a spouse or cotenant with access to one's privacy unit, one assumes the risk of that person consenting to a police request to search. ${ }^{88}$ By conventional social standards, however, the assumption of risk should be greater where strangers or others with inferior possessory rights have been given access to the privacy unit than where spouses or cotenants have been given access. Yet although the "risk" is assumed as to those close to the defendant, the defendant is not considered to have assumed any risk as to, for example, garbagemen consenting to a search ${ }^{69}$ The

band's Property, 69 Dick. L. REv. 69 (1964); Comment, Third Party Consent to Search and Seizure: A Reexamination, 20 J. PUB. L. 313 (1971); Comment, Third Party Consent to Search and Seizure, supra note 59; Note, Third Party Consent to Police Searches, 2 U. SAN Fran. L. REv. 141 (1967).

66 For example, an agency relationship will generally not be inferred unless the agent has performed similar acts in the past. For an extended discussion of the inapplicability of agency concepts to the third party consent situation, see Comment, Third Party Consent to Search and Seizure, supra note 59; Note, Consent Searches: A Reappraisal After Miranda v. Arizona, supra note 48, at 149. See also the discussion in Kelley v. State, 184 Tenn. 143, 197 S.W.2d 545 (1946), which suggests that police must determine whether the wife has the best interests of her husband in mind when she consents. Otherwise, the court held, she would have no right to waive his fourth amendment protections. Requiring such a determination would place an impossible burden on the police.

In cases where the consenting party is the express agent of the defendant, however, and the agent's explicit authority to consent to a police search extends to the searched items, consent would also be valid under the framework proposed in this comment. See, e.g., In re Fried, 161 F.2d 453, 455 (2d Cir.), cert. denied, 331 U.S. 858 (1947); United States v. Antonelli Fireworks Co., 155 F.2d 631 (2d Cir.), cert. denied, 329 U.S. 742 (1946).

67 See Note, Announcement in Police Entries, 80 YALE L.J. 139 (1970).

68 Frazier v. Cupp, 394 U.S. 731 (1969).

69 People v. Krivda, 5 Cal. 3d 357, 486 P.2d 1262, 96 Cal. Rptr. 62 (1971). Although the 
inconsistencies in the assumption of risk justification and the fact that spouses or cotenants are often likely to be unaware that they can refuse to consent make the assumption of risk justification an unsatisfactory framework.

In light of the inadequacies of these traditional justifications for permitting third-party consents and the trend away from exclusive reliance on property concepts in defining the scope of the fourth amendment, a re-evaluation of the rules governing third-party consent is appropriate.

\section{Propertied Privacy and Third-Party Consents}

In the few cases where federal and state courts have actually considered the defendant's reasonable expectations of privacy in determining whether evidence obtained with the consent of a third party should be admitted, they have consistently found the consent invalid; ${ }^{70}$ but they have neglected fully to articulate the two-step test outlined in Katz. Their findings of invalidity have been premised solely on a determination that the defendant's expectations of privacy were invaded.

Privacy has been conceptualized as "the legally recognized freedom or power of an individual ... to determine the extent to which another individual ... may ... obtain or reveal information about him or those for whom he is personally responsible ...."71 For the purposes of establishing a framework for third-party consents, the essential element in this concept is that an individual's "privacy unit" defines not only where he is protected, but also who can permit entry into his privacy unit. Thus Katz had a reasonable expectation that the words he spoke in the phone booth were private except as to the acknowledged listener, but no expectation that the listener would not relay those words to the police. Similarly, one can reasonably expect that the person with whom one shares a home may testify as to what he sees or voluntarily give material to the police, but will not acquiesce in a police request to enter the privacy unit. ${ }^{72}$

court does not mention the term "assumption of risk," the decision implies that one may expect garbagemen to protect a privacy interest.

70 State v. Matais, 51 Haw. 62, 451 P.2d 257 (1969) (friend of defendant consented to a search of defendant's coat while it was in friend's apartment); People v. Smith, 19 Mich. App. 359, 172 N.W.2d 902 (1969) (younger brother of defendant consented to a search of their apartment); State v. Bryant, 287 Minn. 205, 177 N.W.2d 800 (1970) (manager of store consented to police surveillance of restroom stalls); State v. Taggart, 491 P.2d 1187 (Ct. App. Ore. 1971) (landlady consented to search of apartment where tenancy had terminated without tenant's knowledge).

71 Beaney, supra note 3, at 254. See also Douse, supra note 2; Fried, supra note 2.

72 As has been noted above, these definitions of privacy expectations depend to a great extent on the norms that the Supreme Court chooses to establish. It is suggested, 
It is suggested that where an area is protected as to the defendant, and the third party has at least equal possession and control rights but no interest in consenting to a police search, the defendant has a reasonable expectation that the third party will not consent to a search. ${ }^{73}$ Nevertheless, there are situations in which the third party has, in addition to the requisite possessory rights, an interest in consenting sufficient to render the defendant's expectations of privacy unreasonable. Such a countervailing interest arises, for example, where the consenting third party is threatened by the defendant's suspected criminal activity.

In structuring a framework for defining reasonable expectation of privacy as related to third-party consents, it is important to consider that when police request consent to search they cannot be expected to engage in complex evaluations to determine, on the doorstep, whether the consenting party actually has a countervailing interest sufficient to validate the consent. Courts have long taken the position that search and seizure procedures must be easy to administer. ${ }^{74}$ Thus the definition of countervailing interest sufficient to render an expectation of privacy unreasonable must be framed so as to allow easy, practical determination. One means of accomplishing this is by the creation of a presumption of a sufficient countervailing interest where the consenting third party actually initiates ${ }^{75}$ the police activity that leads to the search..$^{78}$ On the other hand, when police initiate the search there must be a presumption that the consenting third party has no countervailing interest sufficient to override the defendant's expectations of privacy. ${ }^{77}$ Except in a few clearly defined circumstances,

however, that the norms proposed in this comment provide a reasonable compromise between the individual's interest in maintaining a privacy unit and society's interest in effective law enforcement.

73 It is impossible to prove by legal analysis that this expectation exists or should be recognized. Nevertheless, common sense indicates that this is the minimum that one should be recognized as properly expecting from someone who shares one's privacy unit. For an interesting discussion of the function of the privacy unit, see Fried, supra note 2.

74 See, e.g., Schneckloth v. Bustamonte, 412 U.S. 218, 231 (1973).

75 For a discussion of the concept of initiation and the purposes it serves, see text and notes at notes $91-95$ infra.

76 Although the presumption of a countervailing interest which is triggered by the third party's initiation of police action need not be irrebuttable, it must be strong if it is to serve its purpose of permitting the police to rely on it in determining whether a subsequent consent will validate a search.

77 Here also the presumption should be a strong one, in this case to protect against police abuse of consent searches. If, for example, a strong request following a police statement of suspicion were allowed to rebut the presumption, the police would be encouraged to exaggerate their stories in order to frighten the third party, and in general the test would be difficult for the courts to administer with any consistency. 
a third-party consent would not justify a police-initiated warrantless search. ${ }^{78}$

Developing the model of propertied privacy with reference to recent third-party consent cases provides a focus for examining the changes this analysis would produce in the existing case law. It also indicates what types of countervailing interests should render a defendant's expectations of privacy unreasonable and reveals several of the problems encountered in administering the proposed changes in third-party consent analysis.

\section{The Propertied Privagy Model}

Recent third-party consent cases may be analyzed according to who initiated the search and who conducted it, resulting in a tripartite classification. First, a number of cases dealt with under the rubric of third-party consents can more realistically be characterized as searches initiated by a third party with no police participation. These searches are private and thus not within the purview of the fourth amendment. Second, searches initiated by the third party but involving some degree of police participation are properly considered as quasi-police searches subject to the restrictions of the fourth amendment, and should be analyzed under the presumption of countervailing interest framework discussed above. Finally, police-initiated searches should be presumed not to be justified by a countervailing interest of the third party. It is suggested that this presumption be rebutted only where: the third party is either a suspected participant in or a possible victim of the suspected criminal activity; ${ }^{79}$ the property to be searched has been abandoned; or suspicion has not yet "focused" on any individual.

\section{A. Private Searches}

In several recent cases reference to the validity of a third-party consent to justify the warrantless seizure was unnecessary. In each case a third party initiated the police contact and, when the police arrived, either the evidence was merely handed over to them,,$^{80}$ or the third

78 For reasons of administrative convenience, the framework proposed here would retain current doctrine of "apparent authority" under which the police are entitled to rely on apparent sufficient possession and control. See, e.g., Mengarelli v. United States, 426 F.2d 985 (9th Cir. 1970). The police would be allowed to rely, for example, on a reasonable appearance that the third person is a victim of the defendant's suspected criminal activities, see text and note at note 79 infra.

79 In these cases the countervailing interest exists and is definable in a way that does not require reference to the initiation of the police contact resulting in the search.

80 Bernovich v. State, 272 So. $2 d 505$ (Fla. 1973); State v. Parton, 487 S.W.2d 523 (Mo. 1972). 
party spontaneously searched and turned over the incriminating evidence. $^{81}$

In Bernovich $v$. State, ${ }^{82}$ for example, the defendant's wife drove his car to her father's home and informed her father of suspicious articles she had noticed under the back seat. He examined the items, put them back under the seat, and called the police. When the officers arrived the father and daughter handed them the incriminating evidence. In State $v$. Parton, 83 a babysitter called the police, claiming that one of the children she was guarding had been raped by the defendant, who lived with the children's mother. When the police arrived, the mother spontaneously gave them incriminating evidence that she had found in the house. In State $v$. Cundy, ${ }^{84}$ the owner of a calf, accompanied by a police officer, complied with the request of a ranch hand to view a calf that the ranch hand suspected his boss was intending to brand as his own. The court found that the search was private and that the officer was merely an onlooker. In each of these cases the search was not a governmental intrusion. Only the court in Cundy, however, correctly analyzed the situation as a private search. ${ }^{85}$

\section{B. Quasi-Police Searches}

Where a third party in possession and control of the premises summons the police and requests that they conduct a search, there is sufficient government involvement to require that fourth amendment protections adhere. ${ }^{86}$ In these circumstances a warrantless search by the police will be reasonable under the propertied privacy analysis only where defendant's expectations of privacy are unreasonable due to a countervailing interest on the part of the consenting third party. The most striking example of a countervailing interest that would render the defendant's expectations of privacy unreasonable exists where the defendant causes or threatens physical harm and the victim seeks police

81 State v. Cundy, 201 N.W.2d 236 (S.D. 1972); Mears v. State, 52 Wis. 2d 435, 190 N.W.2d 184 (1971) (mother's private search revealed the stolen property which she displayed to the police. She subsequently consented to its seizure.).

82272 So. 2d 505 (Fla. 1973).

83487 S.W.2d 523 (Mo. 1972).

84201 N.W.2d 236 (S.D. 1972).

85 Since Burdeau v. McDowell, 256 U.S. 465 (1921), evidence obtained by a private individual has been held admissible regardless of the lawful or unlawful nature of the search. In that case incriminating papers were stolen from the defendant's safe and turned over to federal prosecutors by agents of the company for which the defendant worked. See also, e.g., People v. Johnson, 153 Cal. App. 2d 870, 315 P.2d 468 (1957).

86 See, e.g., Lustig v. United States, 338 U.S. 74 (1949); United States v. Ogden, 484 F.2d 1274 (9th Cir. 1973). 
aid and involves them in a search. In these cases joint possession and control indicates a proximity that compels immediate protective action by the third party, and an expectation that an assaulted person will not seek protection from the police is unreasonable.

In State v. Middaugh, ${ }^{87}$ the defendant's wife sought police aid after an assault on herself and her child by her husband, who was using narcotics. Both she and police engaged in a search which revealed the narcotics. The court held that the wife's consent validated the search because she was in possession and control of the premises. Rather than relying exclusively on the property rights of the third party, the court should have reached its result by holding that the defendant could not have had any reasonable expectation that an assaulted spouse would preserve his privacy. ${ }^{88}$

Likewise, in United States $v$. Lawless ${ }^{89}$ a wife contacted police, claiming that her husband had assaulted her. When officers came to arrest the defendant, the wife initiated a search of their trailer home for a shotgun. An officer accompanied her during the search but took no active role. Looking at eye level into the trailer, however, the officer observed the gun under the sofa. Both the wife and the officer retrieved the weapon. As in Middaugh, the defendant could have no reasonable expectations of privacy with regard to the victim of his assault.

In State v. Mizelle ${ }^{90}$ the consenting party was not the actual target of physical harm or threat, but defendant's expectations of privacy were nonetheless rendered unreasonable. The defendant had incestuous relations with his daughter. Upon discovering the crime the mother

87507 P.2d 42 (Ore. Ct. App. 1973).

88 An additional problem introduced in Middaugh is the effect of the actual presence of the defendant on a third party's ability to consent to a search. Under the traditional justifications for third-party consent, the agency doctrine clearly should require that the request be directed to the defendant, but under the possession and control rule the presence or availability of the defendant should make no difference in the ability of a third party to consent. Few courts, however, have upheld a warrantless search consented to by a third party when the defendant is present. In Tompkins v. Superior Court, 59 Cal. 2d 65, 378 P.2d 113, 27 Cal. Rptr. 889 (1963), the court held a warrantless search unreasonable where the consent of one tenant was objected to by the other tenant. The court stated that mere sharing of legal possession was not sufficient to put one at the mercy of a cotenant.

Where the defendant has victimized the third party, as in Middaugh, the emergency nature of the situation is such that the third-party consent should validate a warrantless search despite defendant's objections. Where the third party merely suspects criminal activity and has initiated a police search, it is unlikely that the defendant will be present. If the defendant is present, the existence of exigent circumstances, such as the possible destruction of evidence should police leave without searching, should determine whether the third-party consent overrides defendant's objections.

89465 F.2d 422 (4th Cir. 1972).

8015 N.C. App. 583, 190 S.E.2d 277 (1972). 
asked the sheriff to search for evidence on the property. Where a minor child is involved, the defendant cannot reasonably expect that his privacy will be protected by a third party who is charged with the care of the child. ${ }^{\text {r1 }}$

In the victim-of-assault cases, the third party's interest that overrode and rendered unreasonable the defendant's expectation of privacy was the interest in being protected from a threat of physical harm. An analogous situation occurs when the person in possession or control of the premises suspects that the defendant is using the premises to engage in criminal activity. The fact that the third party is in sufficient possession and control to trigger the first half of the consent requirement indicates that apprehension of the defendant by the police is likely to involve the third party in criminal proceedings-perhaps as an accessory and at least as a witness. The third party may have an interest in avoiding these involvements. In addition, distaste for the criminal activity or a desire to aid law enforcement may generate a strong countervailing interest. The difficult problem is in determining when the interest is sufficient to render the defendant's expectation of privacy unreasonable.

In the case of a desire to aid law enforcement, for example, a problem arises because any person, if asked in a court of law whether he or she desires to aid law enforcement, is likely to answer affirmatively. Nevertheless, it is likely that most people do not expect a person with whom they have joint possession and control of a privacy unit to acquiesce in a police request to search for evidence against themselves. A test is needed for determining when the countervailing interest is sufficiently great to render the expectation of privacy unreasonable. An administratively feasible standard for measuring the intensity of a third party's interest in having the police search is whether the third party initiated the police activity. Initiation should be defined as initiation of the contact that results in the consent to search. Under this definition if the police, for example, initiate contact with the suspect's wife and explain their suspicions to her, and she then requests that they search, the search is defined as police-initiated and is presumed ${ }^{22}$ to be unreasonable. This definition results in some limits on the police that could be avoided by defining initiation as the first request to search. The initiation of contact definition, however, is administratively simpler because it does not require the courts to interpret fine shades of meaning in

91 This principle might be extended to other members of the family unit so that, for example, the son in a family where the father is threatening assault on the wife may consent to a search.

92 For a discussion of the proper strength of this presumption, see note 77 supra. 
the third party's statements. Moreover, it allows the police to decide at the moment of the search whether a consent will legitimize the search. ${ }^{93}$ The initiation criterion also removes from the police the temptation to exaggerate their fears in the hope of inducing a request to search that would not otherwise be forthcoming.

Validating all third-party consents would, of course, completely solve the problem of administrability. Complete validation might be defended on the ground that in many cases of police initiation the third party nevertheless has a strong interest in aiding law enforcement. In many other cases, however, the third party is likely to be consenting without an awareness that he may refuse, without knowledge of the defendant's activities, or because of a belief that failure to consent would be an admission of the defendant's guilt. In evaluating the likelihood that the third party's consent to a police-initiated search is based on a strong commitment to aid law enforcement, it is suggested that the court should err in favor of minimizing impulsive and unknowing consents that serve no countervailing interest.

Where the third party does initiate the search there is no problem of unawareness of a right to refuse, for it is clear that the third party would not refuse a police request. There is also no possibility that the third party lacks knowledge of the defendant's activities, for it is precisely those activities about which he has notified the police. Finally, the fact of third-party initiation is clear evidence of the strength of the third party's interest in having the police search.

Several cases involving searches initiated by a third party in response to an assault or a threat were discussed above. ${ }^{94}$ Recent third-party cases also provide several examples of nonvictim initiation. In United States $v$. Hughes, ${ }^{95}$ a woman initiated a police search of her home because she wished to put a stop to her lover's illegal counterfeiting activities, which were taking place at her residence. In Stein $v$. United States, ${ }^{96}$ the wife contacted police officers and requested their aid in disposing of narcotics used by her husband. In both cases the evidence was held admissible on the ground that consent had been obtained from a person in possession and control of the premises. The facts would also have supported a finding that the third party's initiation of the police contact indicated the existence of an interest on

98 A more complicated and administratively difficult test, combined with the heavy penalty for mistakes inflicted by the exclusionary rule, might force police to seek a warrant in every case rather than risk an error in evaluating the validity of the consent.

94 See text and notes at notes 87-91 supra.

95441 F.2d 12 (5th Cir. 1971).

96166 F.2d 851 (9th Cir.), cert. denied, 334 U.S. 884 (1948). 
the part of the third party sufficient to render any expectations of privacy by the defendant unreasonable.

In State v. Fassler, ${ }^{97}$ a common carrier had reason to believe that the defendant's trunks contained contraband. The carrier had a statutory right to inspect items in its possession when such a suspicion existed, but asked police to search instead. The court upheld the validity of the search through traditional third-party consent analysis. Under the propertied privacy model, the same conclusion would be reached. The defendant's privacy expectations were rendered unreasonable by the third party's countervailing interest. The third party suspected that its premises were being used to ship contraband and desired police aid to rid itself of the fruits of criminal activity.

In an earlier case with a similar fact situation, the court employed a framework similar to the one suggested in this comment. In Corngold v. United States, ${ }^{98}$ airline employees had the same statutory right as the carrier in Fassler to inspect packages suspected of containing contraband. Government customs agents asked them to exercise that right of search. The court held that the airline employees were acting as police agents and therefore the search was government-initiated. The evidence was thus inadmissible since no search warrant had been obtained. The crucial point was that, left to themselves, the airline employees would not have searched. ${ }^{99}$ The court, however, did not deal with the problem in terms of expectations of privacy or the countervailing interests of the consenting party.

A search initiated by a third party will generally be either a private search or a quasi-police search. Some difficulty arises in determining what degree of police involvement will require one classification or the other. ${ }^{100}$ The problem, however, is only of theoretical interest, because the presumption of countervailing interest created by third-

97108 Ariz. 586, 503 P.2d 807 (1972).

98367 F.2d I (9th Cir. 1966).

99 Corngold provides an example of a situation where the police action did not coerce the consent, but nevertheless was the sole cause of the invasion of the defendant's privacy. It is in preventing abuses by the police in this ambiguous area that the initiation standard is most useful.

100 Police presence at the doorstep or passive presence in the house, prompted by the request of a third party in possession and control, does not violate the normal concept of a private search. See State v. Cundy, 201 N.W.2d 286 (S.D. 1972). Police direction of the search or physical participation of any kind, however, puts the search into the quasipolice category. See, e.g., Machlan v. State, 248 Ind. 218, 225 N.E.2d 762 (1967). Yet if a private individual is conducting an unlawful search in police presence, mere passivity of police will not preclude the court from finding that the individual acted as a police agent. See, e.g., Moody v. United States, 163 A.2d 337 (D.C. Mun. App. 1960). 
party initiation renders quasi-police searches-as well as private searches-reasonable.

\section{Police-Initiated Searches}

When police initiate a search, it cannot be presumed that a consenting third party has a countervailing interest sufficient to render the defendant's privacy expectations unreasonable. To ensure the protection of fourth amendment rights and for reasons of administrative simplicity, there should instead be a presumption that no countervailing interest exists, and, with a few exceptions, a third-party consent should not be held to make an otherwise unreasonable search reasonable. ${ }^{101}$

There are at least four situations, however, where despite the police initiation of the search, third-party consent should be allowed to legitimize the search. First, where the third party in possession and control of the premises has been victimized by the defendant's conduct, ${ }^{102}$ the defendant can have no reasonable expectation that the victim will preserve his privacy against government intrusion. In this case, therefore, the victim's consent to a police-initiated request to search should legitimize the search.

Second, where the consenting party has possession and control and is an apparent coparticipant in the criminal activities, ${ }^{103}$ his consent to the search should suffice. One might have a reasonable expectation of privacy with regard to partners in crime before suspicion focuses, because revelation of evidence incriminating one partner would usually be damaging to the other; once suspicion has focused, however, each partner must reasonably expect that the other, in seeking to cooperate with police for his own benefit, may consent to a search revealing evidence incriminating as to both. ${ }^{104}$

101 See text and note at note 77 supra.

102 See, e.g., Nelson v. Moore, 470 F.2d 1192 (1st Cir. 1972), cert. denied, 412 U.S. 951 (1973); Villene v. United States, 297 A.2d 785 (D.C. Ct. App. 1972); State v. Mizelle, 15 N.C. App. 583, 190 S.E.2d 277 (1972); State v. Middaugh, 507 P.2d 42 (Ore. Ct. App. 1973).

103 See, e.g., Frazier v. Cupp, 394 U.S. 731 (1969), discussed in text at note 105 infra; United States v. Ellis, 461 F.2d 962 (2d Cir.), cert. denied, 409 U.S. 866 (1972), where a coconspirator, wishing to remove suspicion from herself by fully cooperating with the police, allowed police to search her apartment for items belonging to the defendant.

104 The coparticipant exception to the general presumption against police-initiated searches may be highly prone to abuse. The police in many situations will be able to assert, with some credibility, that although their main interest was in the defendant, they also suspected his cotenant or spouse of participation in the crime. One means of protecting against this abuse is close scrutiny by the courts to determine whether the "suspicion of the third party" was in fact a pretext; such a procedure, however, might be difficult for the courts to apply effectively. 
In Frazier v. Cupp, ${ }^{105}$ the Supreme Court validated a search based on a coparticipant's consent, but did not adopt the propertied privacy analysis formulated above. Rather the Court introduced the concept of assumption of risk into the third-party consent area. Unfortunately "assumption of risk" also reaches cases such as spousal or cotenant consent, where it cannot be made consistent with any reasonable expectation of privacy. ${ }^{108}$ The assumption of risk formulation of coparticipant's consents, however, may be seen as merely another way of saying that the defendant's expectations of privacy are unreasonable, insofar as a coparticipant's interest in cooperating to protect himself once suspicion has focused eliminates any reasonable expectation of privacy.

Third, where police have determined that property has been abandoned by the defendant, they may conduct a warrantless search of the premises with the consent of a third party in possession and control. ${ }^{107}$ The very meaning of abandonment is that the defendant no longer has any reasonable expectation of privacy with respect to the property. ${ }^{108}$

Finally, an individual's privacy rights may in rare circumstances be subordinated to important state interests in effective law enforcement - even where no countervailing interest of a third party has rendered the defendant's expectation of privacy unreasonable. If the police are conducting a general investigatory search where suspicion has not yet focused, to require either a search warrant for all premises to be searched or the consent of all occupants of all premises would seriously undermine the ability of the police to conduct general investigations. Thus a general investigatory search might be justified by third-party consent.

105394 U.S. 731 (1969).

106 See, e.g., United States v. Martinez, 450 F.2d 864 (8th Cir. 1971) and United States v. Cataldo, 433 F.2d 38 (2d Cir.), cert. denied, 401 U.S. 977 (1970), where lower courts adopted the assumption of risk framework in cotenant situations.

107 The determination of whether property has been abandoned involves consideration of both the actions and the intent of the defendant. See, e.g., United States v. Wilson, 472 F.2d 901 (9th Gir. 1972); United States v. Roberts, 465 F.2d 1373 (6th Cir. 1972); People v. Carr, 8 Cal. 3d 287, 502 P.2d 513, 104 Cal. Rptr. 705 (1972).

108 Where the fact of abandonment is premised on defendant's denial of ownership, thus allowing police to conduct a warrantless search, courts have recognized that those individuals accused of possessory crimes are faced with a dilemma. See, e.g., United States v. Colbert, 474 F.2d 174 (5th Cir. 1973). In order to challenge the legality of a search, a defendant must establish that he is the victim of an invasion of privacy. Thus to acquire standing to protest, one must claim ownership or possession of the searched object, which in possessory crimes amounts to an admission of guilt. To solve this dilemma the Court has held that, at least with regard to possessory crimes, a defendant may have standing to object without alleging possession. Jones v. United States, 362 U.S. 257 (1960). 
In West $v$. State, ${ }^{109}$ police were looking for a stolen calf. They inquired at all the farms in the vicinity of the theft, and there was no evidence that suspicion had focused on the defendant any more clearly than any other individual in the entire county. Defendant's mother consented to a search which resulted in the discovery of the stolen calf. The court admitted the evidence of the search on the ground that the mother was in possession and control of the premises and thus could consent to a search, but the consent could as easily be held valid on unfocused suspicion grounds.

The Supreme Court implicitly recognized the general investigation exception in Coolidge v. New Hampshire.110 Coolidge is often cited for the proposition that a wife may consent to a search of premises she shares with her husband, but the Court did not in fact reach that issue. Police were conducting a general investigatory search of the neighborhood in which a murder had taken place. At each house they inquired about weapons and the occupant's whereabouts on the night of the crime. Coolidge had already shown his weapons to one set of policemen. The next day, when he was not present, another set of police-unaware of those who had visited earlier and unaware that suspicion was beginning to focus on Coolidge ${ }^{111}$-questioned his wife about her husband's guns and what he had been wearing on the night of the murder. Although the police did not request a search, Mrs. Coolidge retrieved the guns and clothes and asked the police if they wanted to take the articles with them. The Court recognized that there was no search and inferred from police behavior that no search was even intended. Under the model proposed here, the result in Coolidge was correct and would have been so even if the police had sought the wife's consent to search, because at that time suspicion had not focused on any individual.

There are administrative problems in determining when suspicion has properly focused so as to require police to either obtain a search warrant or the defendant's consent. The Court, however, has not found itself unable to deal with the analogous problem of determining when "Miranda warnings" must be given. ${ }^{112}$

It is suggested that when police are merely engaged in the general fact-finding procedure, suspicion has not properly focused. Where they

109503 P.2d 221 (Okla. Crim. App. 1972).

110403 U.S. 443 (1970).

111 It might be argued that where suspicion had focused, as it had on Coolidge, the Court should hold all policemen to constructive notice of that focusing. The Court, however, did not take that position in this case.

112 See, e.g., Orozco v. Texas, 394 U.S. 324 (1969); Mathis v. United States, 391 U.S. 1 (1968); Miranda v. Arizona, 384 U.S. 436 (1966). 
suspect, however, that a given individual has engaged in criminal activity, either due to information obtained from an informant, the individual's past criminal record, or the trail of circumstantial evidence, then suspicion has focused, and the use of third-party consents must be modified as suggested in this comment.

\section{Unreasonable Searches}

The examples discussed above are cases where the consent would have made the search reasonable even under the proposed framework. It is also useful, however, to examine recent cases in which the proposed framework would have invalidated the consent search.

In Commonwealth $v$. Biebighauser, ${ }^{113}$ for example, the defendant was in custody on a murder charge, and the police, rather than asking the defendant for permission to search his house, went to the house and obtained consent from his wife to search areas that she shared with the defendant. The court held that this consent search was constitutional. Under the proposed framework, however, the police would have been required to either ask for consent from the defendant or obtain a warrant. In $M c G e e$ v. State, 114 the defendant lived "as a member of the family"115 with Mr. and Mrs. Farrar, to whom he was not related. At the request of police officers, Mrs. Farrar consented to a search of defendant's room. The court held that Mrs. Farrar had equal rights with the defendant to the use or occupation of the premises, and that she could therefore consent to a search. Under the proposed framework, this consent would not have legitimized the search.

\section{CONCLUSION}

The movement in the Supreme Court's fourth amendment decisions from an emphasis on property concepts to a consideration of both property concepts and reasonable expectations of privacy requires that the third-party consent exception to the rule against warrantless searches be re-examined. The dominance of property concepts in judicial analysis of this subject has fostered inconsistent decisions and complex police guidelines that do not satisfy the courts' own insistence on administrative convenience. ${ }^{116}$

113450 Pa. 396, 300 A.2d 70 (1973).

114451 S.W.2d 709 (Tenn. Crim. App. 1969), cert. denied, 400 U.S. 842 (1970).

115451 S.W.2d at 712.

116 The question of who has apparent authority to consent to a police-initiated search has remained a disturbing problem to police officers and courts despite the Stoner and Chapman decisions. For example, in People v. Miller, 40 Ill. 2d 154, 238 N.E.2d 407 (1968), the defendant was an employee in the private home of an invalid. Police asked and received from the owner of the home permission to search the car in the garage. The 
When privacy is conceptualized as control over the privacy unit, thus incorporating the questions of where one might reasonably expect privacy and whom one might reasonably expect to preserve it, the traditional possession and control test is inadequate. Even those persons who have the requisite possession and control interests (usually the defendant's cotenants or members of his family) should not be allowed to consent to a warrantless search of the premises they share with the defendant unless they have a countervailing interest that renders the defendant's expectations of privacy unreasonable.

Examination of recent case law suggests that guidelines can be established to determine when the defendant's expectations of privacy are unreasonable. When a third party in possession or control of the property to be searched initiates the search, there should be a strong presumption that the party has a countervailing interest sufficient to render the defendant's expectations of privacy unreasonable. Usually the third party's interest is in avoiding use of his privacy unit for criminal activities, or in seeking the aid of the police as the victim of the suspected criminal activity. Where police initiate the search, either on information gained from their informants or from their own investigations, it should be presumed that a third party does not have a countervailing interest sufficient to allow the substitution of his consent for a search warrant. Although several circumstances justifying police-initiated third-party consent searches have been suggested, any exception to the presumption against police-initiated searches must be narrowly construed by the courts if fourth amendment guarantees against unreasonable government intrusion are to be maintained.

In its recent decision in Schneckloth v. Bustamonte, ${ }^{117}$ the Supreme Court held that procedural warnings advising the subject of a search of his right to refuse consent are not necessary. The ignorant or inadvertent consent to a police search permitted by the Court's decision in Schneckloth is particularly troublesome when made by a third party,

court held that the owner's apparent authority to consent, relied on in good faith by the officers, was not sufficient to waive effectively the defendant's fourth amendment rights. The model presented in this comment does not succeed in eliminating all possible problems, but the general limitation of third-party consents to those individuals who initiate a search should result in fewer circumstances where police will be in doubt as to the ability of a third party to consent. An additional problem with current analysis is the difficulty of determining when coercion, which invalidates the consent, exists. See Amos v. United States, 255 U.S. 313 (1921). By generally allowing third-party consents only when the third party initiates the search, inquiries into the voluntariness of the consent, the state of mind of the consenting party, and the effect of the officers' words and actions should be an easier task.

117412 U.S. 218 (1973). 
who is likely to have even less grasp of the consequences of his action than a suspect. The proposed propertied privacy analysis would bring consistency into third-party consent doctrine, thereby simplifying the court's disposition of these cases, increasing the convenience of search and seizure guidelines, and significantly reducing the likelihood of third-party consents resulting from an ignorant acquiescence in a police-initiated search.

Virginia Lee Cook 